\begin{tabular}{|c|c|c|}
\hline BIODIK & $\begin{array}{c}\text { BIODIK: Jurnal IImiah Pendidikan Biologi } \\
\text { ISSN 2580-0922 (online), ISSN 2460-2612 (print) } \\
\text { Volume 7, Nomor 02, Tahun 2021, Hal. 1-10 } \\
\text { Available online at: } \\
\text { https://online-journal.unja.ac.id/biodik }\end{array}$ & BIODIK $(Q)$ \\
\hline
\end{tabular}

Research Article

OPEN ACCESS

\title{
Pengaruh Self Regulated Learning Berbasis Literasi Digital Terhadap Kecerdasan Emosional Siswa
}

\section{(The influence of Self-regulated learning based digilat literacy to emotional intelegence)}

Diyna Auliya Azhary*, Suhendar, Gina Nuranti

Program Studi Pendidikan Biologi,

Fakultas Keguruan dan IImu Pendidikan, Universitas Muhammadiyah Sukabumi

JI. R. Syamsudin, S.H. No. 50, Cikole, Kec. Cikole, Kota Sukabumi, Jawa Barat 43113

Corresponding authors: auliyadiyna@gmail.com

\begin{tabular}{|c|c|}
\hline Informasi Artikel & ABSTRACT \\
\hline $\begin{array}{l}\text { Submit: } 20-02-2021 \\
\text { Diterima: } 18-05-2021 \\
\text { Dipublikasikan: } 01-06-2021\end{array}$ & $\begin{array}{l}\text { This research aims to see the effect of learning carried out by implementing digital } \\
\text { literacy-based learning and conventional learning activities on the intelligence of class } \\
\text { VIII students. In this study, taking a sample of } 2 \text { different classes in SMP Negeri } 15 \\
\text { Sukabumi City with eighth grade students, it can be said that } 20 \text { people as the } \\
\text { experimental class and seventh grade students can be measured } 17 \text { as the control } \\
\text { class. Collecting research data using an emotional intelligence questionnaire } \\
\text { instrument. Analysis of research data using inferential statistics in the form of paired } \\
\text { sample T test. Prior to the hypothesis data, the prerequisite test data used the } \\
\text { normality and homogeneity test to test the indicators and the distribution of the } \\
\text { research data taken. The results showed that there were differences in the scores of } \\
\text { students' intelligence using regulated and conventional independent learning. The } \\
\text { group of students with the application of self-regulated learning based on digital } \\
\text { literacy has a significant hypothesis test (2 tailed) 0.000 <0.05, which means that } \\
\text { there is an average difference between the pretest and posttest results, while } \\
\text { conventional learning does not show an average difference because of the results. } \\
0.163>0.05 \text {. Based on this research, that the application of learning, self-regulated } \\
\text { learning based on digital literacy affects the emotional intelligence of class VIII C } \\
\text { students at SMP Negeri } 15 \text { Sukabumi City. }\end{array}$ \\
\hline & Keywords: Self regulated learning , Digital literacy, emotional intelligence \\
\hline Penerbit & ABSTRAK \\
\hline $\begin{array}{l}\text { Program Studi Pendidikan Biologi } \\
\text { FKIP Universitas Jambi, } \\
\text { Jambi- Indonesia }\end{array}$ & $\begin{array}{l}\text { Penelitian yang bertujuan untuk mengetahui pengaruh dari pembelajaran yang } \\
\text { dilakukan dengan penerapan self-ragulated learning berbasis literasi digital dan } \\
\text { kegiatan belajar secara konvensional terhadap kecerdasan emosional siswa kelas } \\
\text { VIII. Pada penilitian ini mengambil sampel } 2 \text { kelas yang berbeda di SMP Negeri } 15 \\
\text { Kota Sukabumi dengan siswa kelas VIII C berjumlah } 20 \text { orang sebagai kelas } \\
\text { eksperimen dan siswa kelas VIII H berjumlah } 17 \text { sebagai kelas kontrol Mrtode } \\
\text { penelitian menggunakaan metode kuantitatif. Pengumpulan data penelitian dengan } \\
\text { menggunakan instrumen angket kecerdasan emosional. Data penelitian di analisis } \\
\text { dengan menggunakan statistic inferensial berupa uji T paired sample test. Sebelum } \\
\text { pengujian data hipotesis data di uji prasayarat dengan menggunaan uji normalitas } \\
\text { serta homogenitas untuk mengetahui varian dan sebaran data penelitian yang di } \\
\text { ambil. Hasil penelitian mendapatkan bahwa terdapat perbedaan rata-rata terhadap } \\
\text { kecerdasan emosional siswa dengan menggunakan penerapan belajar self regulated } \\
\text { learning dan konvensional. Kelompok siswa dengan penerapan self regulated }\end{array}$ \\
\hline
\end{tabular}


learning berbasis literasi digital memiliki hasil uji hipotesis menunjukan siginifikan (2 tailed) $0,000<0.05$ yang artinya ada perbedaan rata-rata dari hasil pretest dan posttest sedangkan pembelajaran secara konvensional tidak menunjukan adanya perbedaan rata-rata karena hasilnya 0,163 >0,05. Berdasarkan penelitian ini disimpulkan bahwa penerapan pembelajaran self regulated learning berbasis literasi digital berpengaruh terhadap kecerdasan emosional siswa kelas VIII C di SMP Negeri 15 Kota sukabumi.

Katakunci: Self regulated learning , literasi digital, kecerdasan emosional

\section{PENDAHULUAN}

Belajar merupakan kegiatan aktif yang dilakukan seseorang untuk mencapai suatu tujuan. Setiap orang memiliki tujuan yang berbeda tergantung hasil yang ingin dicapai, maka dari itu pada prosesnya siswa yang berperan penting dalam menentukan apa yang harus ia pelajari serta cara mempelajarinya. Tanpa ada keinginan belajar dari siswa maka keberhasilan belajar tidak akan tercapai, dengan begitu siswa harus memiliki keinginan dan kemandirian dalam melakuakan proses pembelajaran (D. P. Sari, 2014).

Untuk mencapai kesuksesan dalam pembelajaran tidak hanya membutuhkan kecerdasan intelektual saja, akan tetapi sangat di butuhkan kecerdasan emosi juga, Goleman (2002) menyatakan bahwa keberhasilan hidup $80 \%$ nya dipengaruhi oleh adanya kecerdasan emosional dan $20 \%$ nya ditentukan oleh kecerdasan intelektual sehingga kecerdasan emosional berperan lebih penting dalam kesuksesan hidup dari pada kecerdasan intelektual, termasuk pada saat proses pembelajaran (Zheng et al., 2020).

Siswa membutuhkan kemampuan kecerdasan emosional alam berinteraksi dengan individu lain, baik dengan lingkungan keluarga, sekolah maupun masyarakat. Siswa di usia remaja memiliki banyak waktu dan lebih sering berhubungan dilingkungan sekolah. Siswa pada masa sekolah menengah pertama (SMP) maupun menengah atas memiliki banyak interaksi dengan lingkngan sekolah nya maka dari itu faktor penting yang mempengaruhi prilaku, sikap ditentukan pada saat remaja khususnya pada perkembangan di sekolah menengah pertama. Pada usia tahap remaja (SMP) meraka akan mulai mencari identitas, dengan mencoba dikendalikan oleh emosional untuk mencari teman yang satu frekuensi atau satu arah pandang demi kenyamanan pada tahap pergaulan (Meier \& Vogt, 2015). Pada masa pencarian identitas inilah berdampak dengan suasana hati siswa, karena akan mengakibatkan perubahan perasaan tanpa alasan, yang dapat menyebabkan penurunan motivasi atau ketidak stabilan belajar, sehingga siswa harus memahami dan mengontrol emosinya agar dapat berengaruh positif terhadap motivasi siswa dalam belajar (Fauziyah \& Isnawati, 2017).

Karakteristik siswa yang memiliki kemampuan self regulated learning menunjukan strategi dalam memonitor atau memantau kemajuan belajar menuju arah tujuan, menyesuaikan serta memperbaiki strategi yang digunakan dalam pencapaian tujuan termasuk dalam mengelola emosi. Pengelolaan emosi yang baik dapat berdampak besar dalam pelaksanaan proses belajar, karena dalam 
pembelajaran siswa harus mampu mengontrol suasana hati agar tidak mengganggu tujuan belajar yang dicapai, dalam hal itu kecerdasan emosional sangat berperan penting disaat kegiatan belajar (Putry et al., 2017).

Siswa membutuhkan kemampuan kecerdasam emosional dalam berinteraksi dengan individu lain, baik dengan lingkungan keluarga, sekolah maupun masyarakat. Siswa di usia remaja memiliki banyak waktu dan lebih sering berhubungan dilingkungan sekolah (Hastuti \& Rahman, 2019) . Siswa pada masa sekolah menengah pertama (SMP) maupun menengah atas memiliki banyak interaksi dengan lingkngan sekolah nya maka dari itu faktor penting yang mempengaruhi perilaku, sikap ditentukan pada saat remaja khususnya pada perkembangan di sekolah menengah pertama . Pada usia tahap remaja (SMP) meraka akan mulai mencari identitas, dengan mencoba dikendalikan oleh emosional untuk mencari teman yang satu frekuensi atau satu arah pandang demi kenyamanan pada tahap pergaulan (Dinata et al., 2016). Pada masa pencarian identitas inilah berdampak dengan suasana hati siswa, karena akan mengakibatkan perubahan perasaan tanpa alasan, yang dapat menyebabkan penurunan motivasi atau ketidak stabilan belajar, sehingga siswa harus memahami dan mengontrol emosinya agar dapat berpengaruh positif terhadap motivasi belajar siswa.

Self regulated learning merupakan suatu proses aktif yang dapat dilakukan siswa dengan melibatkan metakognisi, motivasi dan juga prilaku dalam setiap proses pembelajaran untuk mencapai tujuan belajar yang diinginkan (Zimmerman, 2008). Self-regulation memiliki tahapan yang dilakukan dengan cara memonitor, memodifikasi dan mengevaluasi cara berpikir seseorang (Supriyati, 2019). Bandura (1986) mengemukakan bahwa self-regulation adalah kemampuan yang dimiliki pada setiap individu berupa suatu kemampuan berpikir yang didalamnya dapat mengatur lingkungannya sehingga dapat terjadi sesuai dengan keinginan individu tersebut (Bandura, 1986). Kemampuan tersebut yang menjadikan siswa dapat membuat rencana strategi belajar dan tujuan yang ingin dicapai dalam pembelajaran (Kayacan \& Ektem, 2019).

Selama masa pandemic ini proses pembelajaran dilakukan secara daring. Tentu hal tersebut menjadi suatu perubahan yang drastis bagi siswa karena mereka belum terbiasa untuk melakukan pembelajaran dengan daring, oleh karena itu peranan self reglated learning. erbasis literasi digital sangat penting agar guru dapat tetap menjaga semangat para siswa dalam memahami dan mengikuti setiap pembelajaran yang dilaksanakan sesuai dengan tahapan self regulated learning. Untuk dapat melatih self regulated learning, pentingnya kesadaran diri dari setiap orang, akan tetapi pada kasus ini tenaga pendidikan memiliki peran penting dalam melaih self regulated siswa nya. Karena hal itu guru sebagai tenaga pendidikan memiliki proses untuk melatih siswa nya engan mengutamakan 3 faktor nyaitu metakognitif, perilaku dan motivasi. Self regulated learning juga merupaan pembelajaran yang harus terus menerus dilakukan agar hasil nya dapat maksimal.

Pada zaman 4.0 proses belajar mengajar tidak hanya sebatas transfer materi guru kepada siswa, karena siswa dapat memperoleh materi dari sumber yang lebih banyak seperti internet melalui teknologi digital. Perkembangan teknologi dari tahun ketahun mengalami kemajuan sangat pesat yang dapat dimanfaatkan dari berbagai kalangan termasuk, guru dan siswa. Siswa dan guru dapat berbagi informasi dan berkomunikasi tidak hanya dengan tatap muka secara luring saja, tapi dapat dilakukan secara daring. Hal ini menambah wawasan baru dalam penggunaan teknologi (S. S. Sari, 2020). 


\section{METODE PENELITIAN}

Rancangan penelitian ini menggunakan metode eksperimen semu, sehingga diciptakan sebagai penelitian yang sistematis karena berguna untuk membangun hubungan fenomena sebab akibat (causal-effecct relationship) Desain penelitian eksperimen yang diambil yaitu Quasi experiment design.

Pada penelitian ini memiliki 2 variabel meliputi self regulated learninf berbasis literasi digital sebagai variabel bebas dan kecerdasan emosional sebagai variable terikat. Penelitian ini bertujuan untuk membandinglan kegiatan pembelajaran dengan menggunakan strategi self regulated learning berbasis literasi digital dan pembelajar secara konvensional yang dapat mempengaruhi tingkat kecerdasan siswa kelas VIII di SMP Negeri 15 kota sukabumi. Sampel terdiri dari 37 siswa, dengan pembagian 20 siswa sebagai kelas kontrol dan 17 siswa sebagai kelas eksperimen. Pada kelas eksperimen diberikan perlakukan dengan menerapkan self regulated learning berbasis literasi digital sedangkan pada kelas kontrol dengan menggunakan pembelajaran konvensional.

Teknik pengumpulan data yang digunakan dengan menggunakan instrumen kecerdasan emosional, Prosedur dalam penelitian ini dengan di awali dengan menyiapkan instrument dan validasi instrumen yang akan digunakan. Untuk tahap selanjutnya melakukan pretest terhadap kelas kontrol dan eksperimen dan tahap akhir melakukan posttest terhadap masing-masing kelas tersebut sehingga data terkumpul dan dapat di analisis yang selanjutnya penyusunan laporan. Hasil instrumen berupa kuisioner di analisis dengan statistika deskriptif yang dilakukan uji prasyarat berupa uji normalitas sebaran data dan homogenitas varians. Analisis data statistic yang digunakan untuk menguji hipotesis berupa perhitungan uji-t.

\section{HASIL DAN PEMBAHASAN}

Hasil data penelitian yang di dapatkan adalah skor kecerdasan emosional siswa terhadap penerapan pembelajaran dengan self regulated learning berbasis literasi digital pada kelompok eksperimen yang memiliki jumlah siswa 20 orang, dan juga dara skor kecerdasan emosional terhadap pembelajaran menggunakan konvensional terhadap 17 siswa kelas VIII. Penelitian ini terlihat pengaruh dan tidaknya atas dasar rekapitulasi perhitungan data hasil penelitian yang dapat dilihat pada tabel 1. 
Tabel.1 Hasil hipotesis self regulated learning berbasis literasi digital terhadap kecerdasan emosional

\begin{tabular}{|c|c|c|c|c|c|c|c|c|c|}
\hline \multicolumn{10}{|c|}{ Paired Samples Test } \\
\hline & & \multicolumn{5}{|c|}{ Paired Differences } & \multirow[b]{3}{*}{$\mathrm{t}$} & \multirow[b]{3}{*}{$\mathrm{df}$} & \multirow{3}{*}{$\begin{array}{l}\text { Sig. } \\
(2- \\
\text { tailed })\end{array}$} \\
\hline & & \multirow[b]{2}{*}{ Mean } & \multirow{2}{*}{$\begin{array}{c}\text { Std. } \\
\text { Deviation }\end{array}$} & \multirow{2}{*}{$\begin{array}{l}\text { Std. } \\
\text { Error } \\
\text { Mean }\end{array}$} & \multicolumn{2}{|c|}{$\begin{array}{l}\text { 95\% Confidence } \\
\text { Interval of the } \\
\text { Difference }\end{array}$} & & & \\
\hline & & & & & Lower & Upper & & & \\
\hline $\begin{array}{l}\text { Pair } \\
1\end{array}$ & $\begin{array}{l}\text { PreEks - } \\
\text { PostEks }\end{array}$ & $15.60942^{-}$ & 5.85265 & 1.34269 & 18.43031 & 12.78853 & 11.625 & 18 & 0.000 \\
\hline $\begin{array}{l}\text { Pair } \\
2\end{array}$ & $\begin{array}{l}\text { PreKontr } \\
- \\
\text { PostKontr }\end{array}$ & 1.14669 & 3.12996 & 0.78249 & -0.52115 & 2.81452 & 1.465 & 15 & 0.163 \\
\hline
\end{tabular}

Berdasarkan output pair 1 diperoleh nilai sig. (2 tailed) sebesar $0,000<0,05$ maka dapat diseimpulkan terdapat perbedaan rata-rata hasil belajar siswa untuk pretestkelas eksperimen dengan posttet kelas eksperimen (self regulated learning berbasis literasi digital. Sedangkan berdasarkan output pair 2 dengan penerapan pembelajaran konvensional diperoleh nilai sig. (2 tailed) sebesar 0,163 $>$ 0,05 maka dapat disimpulkan tidak ada perbedaan rata-rata hasil belajar siswa untuk pretest kelas kontrol dan posttest kelas kontrol (konvensional). Hal ini menunjukan hasil $\mathrm{H}_{0}$ ditolak dan $\mathrm{H}_{1}$ diterima.

Tabel.2 Perbandingan N-gain setiap indikator kecerdasan emosional

\begin{tabular}{|c|c|c|c|c|c|c|c|c|}
\hline \multirow{2}{*}{ Indikator } & \multicolumn{4}{|c|}{ Kelas Kontrol } & \multicolumn{4}{|c|}{ Kelas Eksperimen } \\
\hline & Pretest & Posttest & Ngain & Kategori & Pretest & Posttest & Ngain & Kategor \\
\hline Mengenali & & & & & & & & \\
\hline $\begin{array}{l}\text { Emosi Diri } \\
\text { Mengelola }\end{array}$ & 56 & 58 & 0.045455 & Rendah & 59 & 78 & 0.463415 & Sedang \\
\hline $\begin{array}{l}\text { Emosi } \\
\text { Memotivasi }\end{array}$ & 54 & 56 & 0.043478 & Rendah & 56 & 73 & 0.386364 & Sedang \\
\hline $\begin{array}{l}\text { Diri } \\
\text { Mengenli } \\
\text { Emosi }\end{array}$ & 60 & 60 & 0 & Rendah & 61 & 76 & 0.384615 & Sedang \\
\hline Orang Lain & 45 & 47 & 0.036364 & Rendah & 52 & 73 & 0.4375 & Sedang \\
\hline $\begin{array}{l}\text { Membina } \\
\text { Hubungan }\end{array}$ & 63 & 66 & 0.081081 & Rendah & 47 & 73 & 0.490566 & Sedang \\
\hline
\end{tabular}

Berdasarkan data tabel 2, pengambilan data yang dilakukan terhadap kelompok kontrol dan eksperimen yang masing-masing menggunakan data pretest dan posttest. Hasil data pretest dan posttest di kalkulasikan yang menghasilkan nilai $\mathrm{N}$-gain. Pada kelas kontrol dalam setiap indikatornya memiliki nilai $\mathrm{N}$-gain yang di katagorikan rendah, sedangan pada kelas Eksperimen nilai $\mathrm{N}$-gain di kategorikan sedang. Hal ini di membuktikan bahwa pada kelas eksperimen dengan menggunakan penerapan pembelajaran self regulated learning berbasis literasi digital sudah dapat dikatakan cukup efektif karena dapat mempengaruhi kecerdasan emosional siswa.

Kecerdasan emosional merupakan kemampuan seseorang dalam mengatur emosi pada kehidupannya dengan intelegensi untuk menjaga kestabilan emosi dan pengungkapannya melalui keterampilan meliputi mengenali emosi diri, mengelola emosi, memotivasi diri, mengenali emosi orang lain, dan juga membina hubungan kecerdasan emosional merupakan kemampuan seseorang dalam mengatur emosi pada kehidupannya dengan intelegensi untuk menjaga kestabilan emosi dan 
pengungkapannya melalui keterampilan meliputi mengenali emosi diri, mengelola emosi, memotivasi diri, mengenali emosi orang lain, dan juga membina hubungan (Maftukhah, 2018).

Adapun hasil dari pengambilan data dengan skala likert dilhat dari gambar 1 dan gambar 2. Gambar 1 merupakan grafik hasil pengambilan angket kecerdasan emosional pada kelas kontrol. Dari hasil tersebut dapat disimpulkan dengan menggunakan skor interval, yaitu 0\%-19,9\% sangat buruk, 20\%-39,9\% buruk, 40\%-59,9\% cukup, 60\%-79\% baik, 80\%-100\% sangat baik. Pada pretest dan postest menunjukan kategori cukup sehingga tidak ada peningkatan yang signifikan dari dua data yang diambil pada keas kontrol.

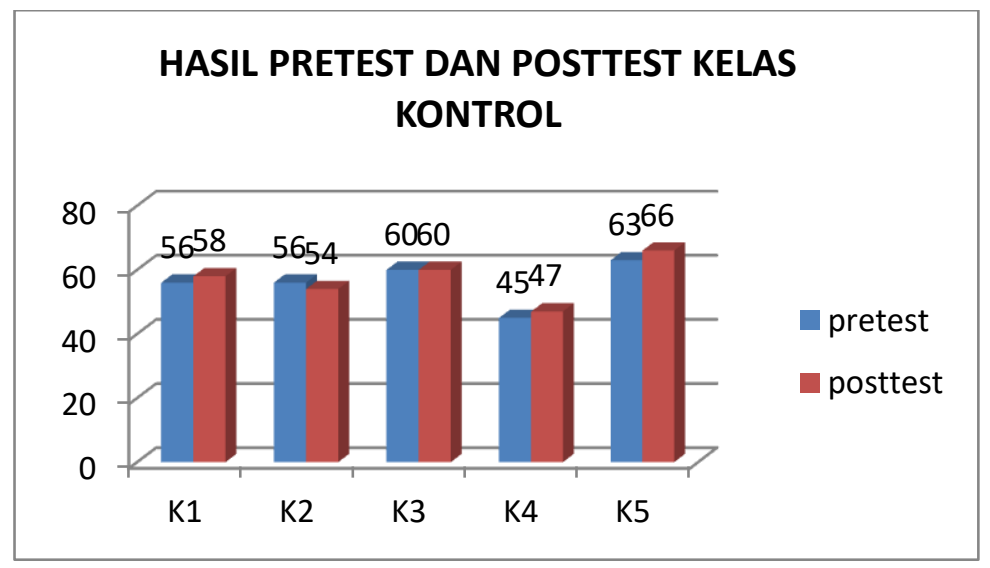

Gambar 1. Grafik hasil pretest dan posttest kelas kontrol

Berdasarkan gambar 2, yang merupakan grafik hasil pretest dan posttest kelas eksperimen menunjukan perbedaan nilai yang siginifikan, pada pretest siswa mendapatkan skor dengan kategori cukup sedangkan pada skor posttest siswa mendapatkan skor baik. hal ini membuktikan bahwa pembelajaran self regulated learning berbasis literasi digital dapat berpengaruh serta meningkatkan masing-masing indikator dari kecerdasan emosional.

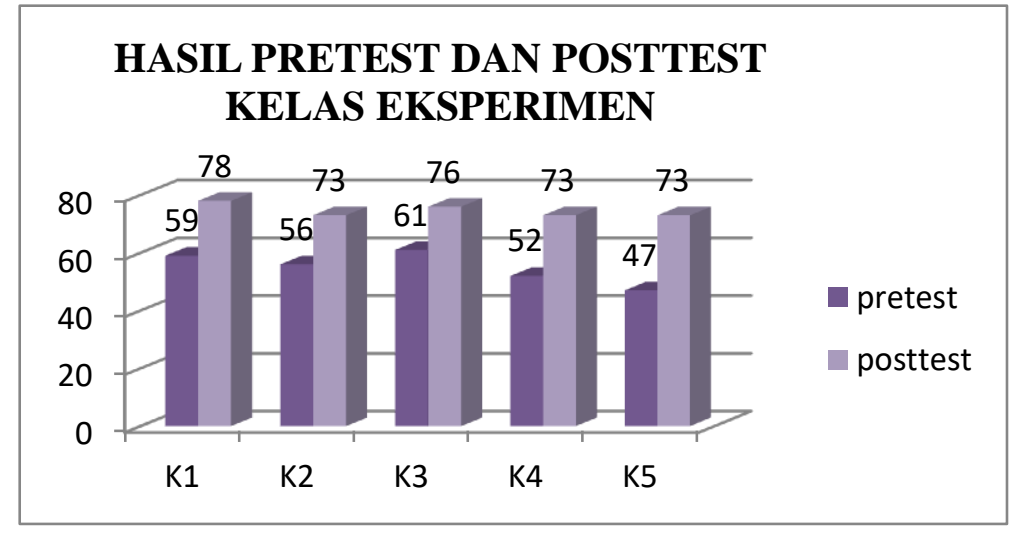

Gambar 2. Grafik hasil pretest dan posttest kelas Eksperimen

Berdasarkan penelitian yang telah dilakukan melalui deskripsi hasil data penelitian, bahwasanya kelompok siswa yang mengikuti pembelajaran dengan penerapan self-regulated learning berbasis literasi digital memiliki kecerdasan emosional lebih tinggi di bandingkan dengan kelompok belajar menggunakan pembelajaran yang konvensional. Dibuktikan dengan hasil data rata-rata yang didapatkan melalui instrumen penelitian berupa angket.. Hal ini diartikan bahwa terdapat perbedaan 
kemampuan kecerdasan emosional yang signifikan antara kegiatan belajaran dengan penerapan self regulated learning dengan pembelajaran konvensional. Tahapan pembelajaran menggunakan self regulated learning mengikui tahapan dari seorang ahli yaitu Zimmerman, prosesnya sebagai berikut.

Pada tahap awal pembelajaran dengan self regulated learning berbasis literasi digital dengan perencanaan dan pemikiran dalam pembuatan tujuan belajar. Guru mengarahkan siswa disetiap pertemuan untuk mengetahui tujuan belajar yang akan dilakukan siswa. Oleh karena itu siswa memahami hal-hal yang perlu ia capai dalam kegiatan belajar termasuk dalam pengerjaan tugas Siswa merencanakan strategi dengan cara menjadwalkan waktu untuk belajar dan juga mengerjakan tugas sehingga waktu dalam kesehariannya dapat terorganisir dengan baik. seperti yang terdapat pada penelitian sebelumnya yang menjelaskan bahwa hal tersebut sangat perlu untuk mengetahui sejauh mana mereka dapat mengatur diri dan mengontrol diri dalam setiap tindakan ataupun permasalahan yang mereka hadapi (Kayacan \& Ektem, 2019).

Setelah melalukan perencanaan dan juga pemikiran siswa menerapkan startegi yang telah mereka rencanakan sebelumnya, karena sebelumnya mereka telah melakukan pemikiran yang matang dan terorganisir sehingga pada saat pelaksanaanya siswa dapat melakukannya dengan baik, karena mereka memiliki target atau capaian yang jelas. Disini diperlukannya motivasi yang dapat mendorong mereka melakukan tindakan yang konsisten. Motivasi merupakan bagian dari kecerdasan emosional yang sangat mempengaruhi diri, karena hal tersebut termasuk dalam imajinasi, pengarahan, pemusatan perhatian serta strategi belajar yang ditanggung oleh diri sendiri agar terlaksananya kegiatan belajar dan tugas yang maksimal sesuai dengan perencanaan tujuan (Littlejohn et al., 2016).

Tahap terakhir yaitu dengan refleksi diri, ditahap ini siswa telah mendapatkan hasil dari tindakan mereka dalam kegiatan belajar, sehingga mereka mmeiliki pengalaman belajar melalui penilaian diri. Pada tahap refleksi siswa mengevaluasi bisa dengan tanggapan teman maupun membandingkan hasil belajar dirinya dengan orang lain, upaya membandingan informasi tersebut diperoleh melalui pemantauan diri dengan standar tujuan yang telah ditetapkan dari awal perencaaan. Pada fase ini siswa mengevaluasi hasil capaian belajarnya, mengungkapkan reaksi-reaksi afektif, dan juga mengevaluasi penyebab keberhasilan atau kegagalan untuk dilakukan perbaikan pada perencanaan tugas belajar berikutnya.

Kecerdasan emosional memiliki beberapa indikator pada prosesnya kegiatan pembelajaran self-reglated learning berbasis literasi digital ini dapat mempengaruhi indikator-indikator kecerdasan emosional. Diantaranya sebagai berikut:

Mengenali emosi, hasil data penelitian pada indikator ini menunjukan peningkatan yang semula $56 \%$ menjadi $78 \%$ yang dilihat dari interval mulai pada test awal termasuk kategori cukup dan seletah penerapan pembelajaran self regulated learning termasuk kategori baik. Siswa mengalami pengaruh yang dapat meningkatkan kecerdasan emosional pada indikator mengenali empsi. Siswa dapat mengetahui serta merasakan pada situasi dan keadaan yang direncanakan maupun tidak, sehingga mereka dapat mengetahui hal-hal yang perlu mereka lakukan dan kendalikan juga digunakan untuk memandu pada saat pengambilan keputusan oleh diri sendiri, memiliki tolak ukur yang realistis atau sesuai dengan fakta dan kepercayaan diri yang tinggi (AI \& Damayanti, 2020). Didalam pembelajaran melalui penerapan self regulated learning berbasis literasi digital menekankan nilai perilaku dimana 
siswa harus menunjukan perilaku yang baik sesuai dengan penempatan keadaan terhadap teman, guru maupun lingkungan dimana kegiatan pembelajaran dilaksanakan.

Mengelola emosi, hasil data penelitian pada indikator ini menunjukan peningkatan yang semula pada kategori cukup 56\% mengalami peningkatan dengan hasil 73\% dikategori baik. siswa menunjukan pengaruh dalam mengelola emosi sebagai salah satu indikator kecerdasan emosioanl. Pada pengelolaan emosi siswa mampu menangani emosi yang terdapat pada diri sendiri sehingga memiliki dampak positif terhadap pelaksanaan tugas yang telah guru berikan, siswa dapat bertanggung jawab terhadap hasil pengerjaan tugas karena dapat mengendali Mood agar pelaksanaan pembelajaran maupun pengerjakaan tugas dapat diselesaikan. Hal ini ditunjukan dengan sikap peka terhadap intuisi atau kata hati, sehingga mereka sanggup menunda kegiatan lain sebelum tercapainya suatu tujuan serta dapat bangkit dari suatu tekanan emosi atau frustasi (Al \& Damayanti, 2020). Pada tahap penerapan self regulated learning berbasis literasi digital terdapat nilai metakognisi berupa perencanaan tujuan sehingga dalam prosesnya siswa harus dapat menerapkan hal-hal yang sesuai dengan rencana agar dapat hasil optimal dengan begitu bersinambungan dengan cara mereka dapat mengelola emosinya dengan baik.

Memotivasi diri, hasil data penelitian pada indikator ini menunjukan peningkatan yang semula pada kategori cukup $61 \%$ mengalami peningkatan dengan hasil $76 \%$ dikategori baik. motivasi yang baik dalam diri siswa dapat mampu mempengaruhi hasil belajar yang optimal. Kemampuan motivasi diri ini memiliki ketekunan serta kekuatan untuk mengendalikan dorongan hati menggunakan hasrat pada diri sendiri untuk menggerakkan serta menuntun siswa menuju sasaran atau goal, terdapat siswa yang tidak memiliki motivasi dalam belajar sehingga tugas-tugas tidak terselesaikan dengan baik. Pada penerapan self-regulated learning ini mendorong siswa untuk memilki motivasi dengan melihat kegiatan pembelajaran yang menarik bagi siswa dan juga pemberian motivasi secara eksternal pada setiap pertemuan dalam kegiatan belajar dan hal ini dijelaskan pada jurnal penelitian yang berjudul Motivation and self-regulated learning in MOOCs (Littlejohn et al., 2016). Hal ini dapat membantu dalam pengambilan inisiatif yang tepat dan juga dalam mempertahankan diri menghadapi kegagalan.

Mengenali emosi oranglain, hasil data penelitian pada indikator ini menunjukan peningkatan yang semula pada kategori cukup 52\% dengan pengaruh hasil menjadi $73 \%$ dikategori baik. Pada indikator ini siswa berhubungan langsung dengan orang lain selain dirinya sendiri. Siswa harus dapat menempatkan dirinya dalam situasi dengan melihat keadaan orang lain, pada hal ini siswa dapat membaca bagaimana orang lain bertindak dan bersikap yang juga mempengaruhi segala tindakan yang mereka lakukan. Penerapan self regulated learning berbasis literasi digital membantu siswa memahami dan melihat situasi orang lain dengan melihat kognisi yang pernah mereka analisis sebelumnya. Pada hal mengenali emosi orang lain siswa dapat merasakan sesuatu yang dirasakan orang lain, sehingga mampu memahami perspektif mereka, menumbuhkan hubungan yang baik, dan juga memposisikan diri untuk menghadapi berbagai macam orang.

Membina hubungan, hasil data penelitian pada indikator ini menunjukan peningkatan yang semula pada kategori cukup 56\% menjadi $73 \%$ dikategori baik. selai mengenali emosi orang lain siswa juga membina hubungan baik dengan orang lain dan dapat membaca situasi serta kondisi di lingkungan sosial. Self regulated learning berbasis literasi digital mengarahkan siswa dapat berperilaku baik terhadap orang lain termasuk kepada teman maupun guru yang membimbing mereka. Contoh 
penerapan nya dimana siswa saling berkomentar baik terhadap hasil tugas yang telah guru berikan. Pada tahap membina hubungan dapat memiliki interaksi komunikasi yang lancar yang berguna untuk memimpin, bermusyawarah serta menyelesaikan konflik (Maftukhah, 2018).

Pembelajaran dengan penerapan self regulated learning berbasis literasi digital ini bermaksud agar cara pembelajaran yang dilakukan siswa kelas VIII dapat terpusat pada diri siswa itu sendiri dan guru sebagai fasilitator dalam pengembangan belajarnya. Self regulated learning itu sendiri menonjolkan indikator berupa metakognisi, motivasi serta prilaku siswa yang ketiga hal tersebut sangat dapat berpengaruh dalam kecerdasan emosional siswa (Utaminingsih, 2017)

Berdasarkan hasil data penelitian kecerdasan emosional dapat terlihat pengaruh peningkatan dalam setiap indikator dan yang menonjol pada indikator mengenali emosi dan membina hubungan yang memiliki nilai $\mathrm{N}$-gain paling tinggi dianatara indikatorr lainnya. Hal itu menjelaskan bahwa penerapan self regulated learning memiliki pengaruh peningkatan pada tahap sedang terhadap kecerdasan emosional siswa. Selain itu penerapan self regulated learning pada prosesnya memiliki 3 tahapan utama yaitu perencanaan dan pemikiran, pelaksanaannya dan terakhir refleksi diri yang didalamnya terdapat nilai metakognisi, motivasi dan perilaku. Ketiga fase tersebut dijelaskan oleh Pintrich, Zusho dan Zimmerman, mengatakan bahwa terdapat 3 (tiga) fase siklus dalam self regulated learning yaitu pemikiran dan perencanaan atau disebut forethought and planning, pemantauan kinerja atau performance monitoring dan refleksi kinerja/ atau reflection on performance (Zimmerman, 2008).

\section{SIMPULAN}

Self Regulated learning merupakan salah satu pendekatan pembelajaran yang digunakan untuk dapat berpengaruh dalam peningkatan kecerdasan emosional anak, khususnya siswa kelas VIII, sehingga mampu membentuk karakter yang baik dalam kehidupan sehari-hari maupun pada saat kegiatan belajar. Hasil data penelitian yang didapatkan yaitu self regulated learning dapat berpengaruh terhadap kecerdasan emosioanal siswa melalui tahapan pengambilan data pretest dan posttest dengan bukti analsiis dengan menggunakan SPSS. Pada kelima indikator kecerdasan emosional indikator mengenali emosi dan membina hubungan memiliki pengaruh peningkatan yang paling tinggi dilihat dari hasil N-gain nya.

\section{UCAPAN TERIMAKASIH}

Puji serta syukur kepada semua pihak yang membantu dalam menyelesaikan penelitian dan menuliskan laporan yang berjudul "pengaruh self-regulated learning terhadap kecerdasan emosional siswa". Kepada kepala sekolah serta guru SMP negeri 15 yang mengizinkan untuk melakukan penelitian di sekolah tersebut. ucapan terimakasih juga kepada pihak-pihak yang sudah mendukung dan men-support untuk menyelesaikan penelitian ini.

\section{RUJUKAN}

Al, S. F. I., \& Damayanti, I. P. S. (2020). Pengembangan Kecerdasan Emosional Peserta Didik Di Sekolah Dasar Melalui Pendidikan Karakter. Jurnal Pendidikan Dasar Indonesia, 4(1), 137-146.

Bandura. (1986). Social Foundations of Thought and Action: a Social Cognitive Theory. Englewood Cliffs New Jersey: Prentice-Hall Inc. 
Dinata, P. A. C., Rahzianta, \& Zainuddin, M. (2016). Self Regulated Learning sebagai Strategi Membangun Kemandirian Peserta Didik dalam Menjawab Tantangan Abad 21. Seminar Nasional Pendidikan Sain, 1(1), 139-146.

Fauziyah, T. A., \& Isnawati. (2017). Pengembangan Media Permainan Sains Quartet untuk Meningkatkan Hasil Belajar dan Keterampilan Berkomunikasi. E-Journal Unesa, 05, 131-137.

Hastuti, R., \& Rahman, U. (2019). Pengaruh Regulasi Diri ( Self Regulation ) Dan Motivasi Belajar Terhadap Hasil Belajar Biologi Pada Peserta Didik Kelas Xi Mia MAN Bulukumba. Jurnal Al-Ahya, 1(2), 42-52.

Kayacan, K., \& Ektem, I. S. (2019). The effects of biology laboratory practices supported with selfregulated learning strategies on students' self-directed learning readiness and their attitudes towards science experiments. European Journal of Educational Research, 8(1), 313-323. https://doi.org/10.12973/eu-jer.8.1.313

Littlejohn, A., Hood, N., Milligan, C., \& Mustain, P. (2016). Learning in MOOCs: Motivations and selfregulated learning in MOOCs. Internet and Higher Education, 29, 40-48. https://doi.org/10.1016/j.iheduc.2015.12.003

Maftukhah, N. A. (2018). Kemampuan Problem Solving Matematika Siswa. Jurnal Al-Hikmah, 6, 1-10.

Meier, A. M., \& Vogt, F. (2015). The potential of stimulated recall for investigating self-regulation processes in inquiry learning with primary school students. Perspectives in Science, 5, 45-53. https://doi.org/10.1016/j.pisc.2015.08.001

Putry, N. D., Armen, \& Putri, D. H. (2017). Hubungan Kemampuan Self-Regulated Learning Dengan Hasil Belajar Ipa Siswa SMPN 3 Padang. Berkala Ilmiah Bidang Biologi, 1(2), 210-217.

Sari, D. P. (2014). Mengembangkan Kemampuan Self Regulation: Ranah Kognitif, Motivasi Dan Metakognisi. 16-39.

Sari, S. S. (2020). Kemampuan Literasi Digital pada Kalangan Siswa SMP dan SMA Di Daerah Pedesaan Kabupaten Blitar. IImu Informasi Dan Perpustakaan.

Sugiyono. (2017). Metode Penelitian Kuantitatif, Kualitatif dan R\&D. Alvebeta CV.

Supriyati, D. (2019). Pengaruh Metode Pembelajaran Hypnoteaching Terhadap Self Regulation Dan Kemampuan Berpikir Kritis Siswa Sma Negeri 1 Jati Agung Kelas X Pada Mata Pelajaran Biologi. In Society. Universitas Islam Negeri Raden Intan.

Utaminingsih, D. (2017). Studi Investigasi Hubungan Antara Metakognisi , Self- regulasi dan Motivasi Belajar Siswa. Jurnal Pendidikan Progresif, 2(1), 13-20. https://doi.org/https://doi.org/10.23960/jpp.v7.i1.201702

Zheng, J., Xing, W., Zhu, G., Chen, G., Zhao, H., \& Xie, C. (2020). Profiling self-regulation behaviors in STEM learning of engineering design. Computers and Education, 143(July 2019), 103669. https://doi.org/10.1016/j.compedu.2019.103669

Zimmerman, B. J. (2008). Investigating self-regulation and motivation: Historical background, methodological developments, and future prospects. American Educational Research Journal, 166-183. 